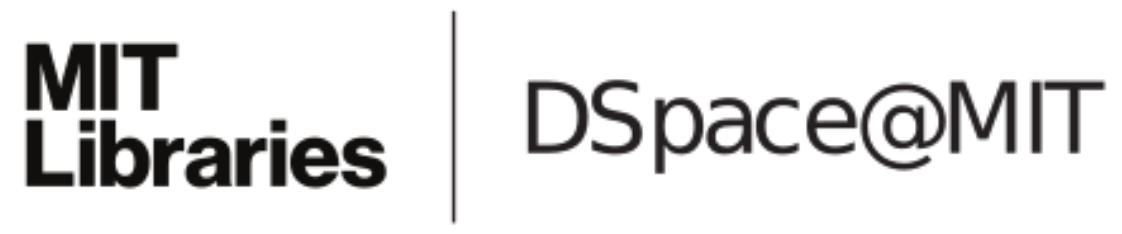

MIT Open Access Articles

Simulation-based analysis of the use of PCM-wallboards to reduce cooling energy demand and peak-loads in low-rise residential heavyweight buildings in Kuwait

The MIT Faculty has made this article openly available. Please share how this access benefits you. Your story matters.

Citation: Soares, Nelson et al. "Simulation-based analysis of the use of PCM-wallboards to reduce cooling energy demand and peak-loads in low-rise residential heavyweight buildings in Kuwait." Building Simulation 10, 4 (August 2017): 481-495 @ 2017 Tsinghua University Press and Springer-Verlag Berlin Heidelberg

As Published: http://dx.doi.org/10.1007/s12273-017-0347-2

Publisher: Springer Nature

Persistent URL: https://hdl.handle.net/1721.1/122028

Version: Author's final manuscript: final author's manuscript post peer review, without publisher's formatting or copy editing

Terms of use: Creative Commons Attribution-Noncommercial-Share Alike 


\title{
Simulation-based analysis of the use of PCM-wallboards to reduce cooling energy demand and peak-loads in low-rise residential heavyweight buildings in Kuwait
}

\author{
N. Soares ${ }^{\text {a, b, c }}$, Christoph F. Reinhart ${ }^{\mathrm{d}}$, Ali Hajiah ${ }^{\mathrm{e}}$ \\ ${ }^{a}$ MIT-Portugal Program, EFS Initiative, University of Coimbra, Coimbra, Portugal \\ b ADAI, LAETA, Department of Mechanical Engineering, University of Coimbra, Coimbra, Portugal \\ ${ }^{\mathrm{c}}$ ISISE, Department of Civil Engineering, University of Coimbra, Coimbra, Portugal \\ ${ }^{\mathrm{d}}$ Massachusetts Institute of Technology, Cambridge, MA 02139, USA \\ ${ }^{\mathrm{e}}$ Kuwait Institute for Scientific Research (KISR), Kuwait
}

\section{The final publication is available at Springer via https://dx.doi.org/10.1007/s12273-017-0347-2}




\title{
Simulation-based analysis of the use of PCM-wallboards to reduce cooling energy demand and peak-loads in low-rise residential heavyweight buildings in Kuwait
}

\author{
N. Soares ${ }^{\text {a, b, c }}$, Christoph F. Reinhart ${ }^{\mathrm{d}}$, Ali Hajiah ${ }^{\mathrm{e}}$ \\ ${ }^{a}$ MIT-Portugal Program, EFS Initiative, University of Coimbra, Coimbra, Portugal \\ b ADAI, LAETA, Department of Mechanical Engineering, University of Coimbra, Coimbra, Portugal \\ ${ }^{\mathrm{c}}$ ISISE, Department of Civil Engineering, University of Coimbra, Coimbra, Portugal \\ ${ }^{\mathrm{d}}$ Massachusetts Institute of Technology, Cambridge, MA 02139, USA \\ ${ }^{\mathrm{e}}$ Kuwait Institute for Scientific Research (KISR), Kuwait
}

\begin{abstract}
Between 2000 and 2015, annual electric peak demand in Kuwait has doubled to 15000 MW and the Ministry of Energy and Water expects this number to double once more by 2030 attributing $70 \%$ of this growth to new housing projects. Within this context, this manuscript evaluates the effect of incorporating PCM-wallboards in low-rise airconditioned residential heavyweight buildings in Kuwait. Using an EnergyPlus single-zone model, a parametric study is performed considering several window-to-wall ratios (WWRs), different solar orientations and some PCMwallboards configurations. The main study goals are to: $(i)$ explore the validity of a single PCM-wallboard solution that can be universally applied throughout residential buildings in Kuwait; (ii) evaluate the impact of PCMwallboard on the reduction of both cooling demand and peak-loads; (iii) provide some guidelines for incorporating PCM-wallboards in Kuwait. Following an extensive parametric study, a $4 \mathrm{~cm}$ thick PCM-wallboard with a meltingpeak temperature of $24{ }^{\circ} \mathrm{C}$ yielded the lowest annual cooling demand across a variety of room orientations and WWRs assuming cooling-set point of $24^{\circ} \mathrm{C}$. Its implementation lead to annual cooling energy savings of $4-5 \%$ across all the case-studies. Regarding the impact throughout the year, cooling demand and peak-loads can be reduced by $5-7 \%$ during summer months. The average daily cooling loads can be reduced by $5-8 \%$.
\end{abstract}

\section{Keywords}

PCM-wallboards, residential buildings, hot arid climate, cooling energy demand, dynamic simulation. 


\section{Introduction}

In recent decades, Kuwait has experienced substantial building construction activities which cause significant strain on the country's electricity grid. Between 2000 and 2015, annual electric peak demand has doubled to 15000 MW and the Ministry of Energy and Water expects this number to double once more by 2030 attributing $70 \%$ of this growth to new housing projects (Al Tayyar 2015). Moreover, previous work has shown that in established residential neighborhoods in Kuwait about half of the electricity use and 70\% of peak demand in buildings stem from cooling energy demand (Reinhart et al. 2015). The above described, ever-growing peak demands have led to recurring summer blackouts in some residential areas. Given that Kuwait is an oil-exporting country, a possible reaction to the development in the residential sector could be to increase electricity generation. However, oil is the country's only natural resource and its main source of revenue (Ministry of Electricity and Water 2010) and while as late as 1980 , only $10 \%$ of the produced energy was consumed locally, this percentage was close to $40 \%$ in 2015 .

What are alternative options for the country? At $13000 \mathrm{kWh}$ per person, annual energy use per capita in Kuwait is among the highest in the world (Alotaibi 2011). While this use can be partly attributed to the harsh summer climate, other contributing factors are inefficient construction practices and installed equipment, as well as energy-intensive lifestyle choices (Al-Mumin et al. 2003). It should therefore become a government priority to manage and reduce building energy use in Kuwait to ensure the country's long-term prosperity. To further this goal, the energy conservation code of the Ministry of Electricity and Water (Ministry of Electricity and Water 2010) establishes several recommendations to enhance the energy efficiency of buildings (including insulation, glazing, lighting and ventilation requirements) and to reduce power ratings of air-conditioning systems. (Al-ajmi and Hanby 2008) carried out a parametric study on the simulation of the energy consumption of residential buildings in Kuwait using TRNSYS-IISIBAT environment. The authors proposed several features that should be adopted to achieve more energy efficient buildings in Kuwait, including: the reduction of the amount of uncontrolled air infiltration rates; the control of the window area and the orientation and placement of the main window facades (windows in the Kuwaiti environment should face toward the north-south direction), and the use of certain treatments to the glazing to reduce heat gains. However, only traditional sensible construction materials are considered in both documents. To complement these works, this manuscript explores the incorporation of PCM-wallboards in low-rise air-conditioned residential heavyweight buildings in Kuwait.

PCMs are materials that undergo melting/solidification at a nearly constant temperature, storing/releasing great amounts of energy due to the latent heat involved in the solid-liquid phase change processes. Therefore, PCMs are very suitable for thermal management and thermal energy storage (TES) applications. Ideally, PCMs to be used in TES systems should have a melting/solidification temperature in the practical range of application and they must 
have a high latent heat of fusion and a elevated thermal conductivity (paraffins used in buildings applications typically have low thermal conductivity, which can compromise some applications). Moreover, to be used in the design of TES systems, PCMs should have desirable thermophysical, kinetic, chemical and economic properties as suggested by (Soares et al. 2013) and (Cabeza et al. 2011). PCMs are mainly classified as organic, inorganic and eutectic. Organic PCMs are further described as paraffins and non-paraffins. Inorganic PCMs are further described as hydrated salts and metallics. Several applications of PCMs can be found in literature, including: PCM enhanced wallboards and other PCM walls; shape stabilized PCM (SSPCM) enhanced elements; PCM bricks; PCM enhanced concrete systems and mortars; PCM Trombe walls; PCM shutters, window blinds and translucent PCM walls; PCM enhanced ventilated façades; PCM enhanced photovoltaics; PCM enhanced HVAC systems, etc..

The advantages of incorporating PCMs in buildings were recently pointed out and reviewed by many authors (Soares et al. 2013; Cabeza et al. 2011; de Gracia and Cabeza 2015; Sharma et al. 2009; Tyagi and Buddhi 2007; Kuznik et al. 2011; Zhou et al. 2012; Zhang et al. 2007; Pomianowski et al. 2013; Baetens et al. 2010; Khudhair and Farid 2004; Osterman et al. 2012; Zhu et al. 2009), and several numerical and experimental studies have been carried out to assess the thermal performance of different PCM-based wallboards. The studies carried out by (Kuznik et al. 2008), (Kuznik and Virgone 2009) and (David et al. 2011) provided important information about the optimization of a paraffin-based wallboard for building use. These studies also list the importance of several aspects to be considered in the assessment of the heat transfer with solid-liquid phase change through PCM-based wallboards. (Soares et al. 2014) numerically evaluated the impact of incorporating PCM-wallboards in the heating and cooling energy demand of an air-conditioned lightweight steel-framed (LSF) residential room when implemented under several European climates. A multi-dimensional optimization study was carried out by combining EnergyPlus and GenOpt tools. The authors evaluated different thermophysical properties of the PCM (enthalpy-temperature and thermal conductivity-temperature functions) and design parameters, such as the solar absortance of the inner surfaces, the thickness and location of the PCM-drywalls in the room, air-infiltration rates, solar gains, internal gains, and set-points to conclude that PCM-wallboards can contribute for the annual cooling and heating energy savings in a passive way. The authors provided some guidelines for the incorporation of PCMdrywalls in LSF residential buildings in Europe. As stated by (de Gracia et al. 2015), this attempt to develop specific solutions for different locations based on their climate can be a good approach to foster the implementation of a specific technology. (Saffari et al. 2016) developed an EnergyPlus based methodology to evaluate the energy performance of a PCM-enhanced building model in Madrid. The authors used the Fanger thermal comfort model to control the HVAC operation and to evaluate the economic impact of integrating PCMs in buildings. The results showed that PCMs improve the cooling and heating energy performances of the most evaluated cases. In order to 
evaluate the potential of a PCM-wallboard constituted of 60 wt.\% of microencapsulated paraffin within a copolymer, a renovated office building in Lyon was monitored during one year by (Kuznik et al. 2011). A room was equipped with PCM-wallboards in the lateral walls and in the ceiling, and another room, identical to the first one, was not equipped but also monitored. The results showed that PCM-wallboards can enhance the thermal comfort of occupants. (Mandilaras et al. 2013) experimentally evaluated the impact on PCM-wallboards in the thermal performance of a Mediterranean residential building. The authors concluded that the thermal mass of the walls can be enhanced during late spring, early summer and autumn (when PCMs are activated). The study was conducted for unoccupied house conditions, which can be problematic since internal loads may significantly affect the dynamics of the phase change processes of the PCM. It can be seen that, several studies concerning the application of PCMwallboards in real buildings have been carried out in order to evaluate the influence of PCM-wallboards in more real-life conditions. However, no guidelines about the incorporation of PCM-wallboards in heavyweight construction in the dry desert climate conditions of Kuwait are found in the literature. Low-rise heavyweight construction is very widespread in Kuwait and, regarding the residential sector, low-rise buildings are the most representative Kuwaiti buildings. Therefore, this category of buildings will be used as case study in this paper.

The main goals of this work are therefore to: $(i)$ explore the validity of a single PCM-wallboard solution (thickness and the melting-peak temperature) that can be universally applied throughout low-rise residential heavyweight buildings in Kuwait; (ii) evaluate the impact of PCM-wallboards on the reduction of both cooling demand and peak-loads; (iii) provide some guidelines for incorporating PCM-wallboards in Kuwait. This study forms part of an MIT-Kuwait Signature Project called Sustainability of Kuwait's Built Environment which aims at promoting an energy and carbon-efficient built environment in Kuwait.

\section{Methodology}

A parametric study is carried out by using a single-zone, air-conditioned residential building model in EnergyPlus (EnergyPlus 8.0.0 2014) built according to the 2010 building energy code of Kuwait (Ministry of Electricity and Water 2010). The KISR Kuwait Intl Airport - KWT weather data file is used to simulate Kuwaiti climate (Fig. 1) (EnergyPlus 8.0.0 2014). In agreement with this data file, the climate of Kuwait is classified as BWh - Subtropical hot desert (lat. $15-25^{\circ} \mathrm{N}$ ) according to the Köppen climate classification. The climate of Kuwait shows unbearably hot dry periods in summer. The warmest week, on average, is in August with an average temperature of $37.85{ }^{\circ} \mathrm{C}$. The maximum temperature during summer can reach $49.7^{\circ} \mathrm{C}$. The coolest month on average is January, with an average temperature of about $14.76^{\circ} \mathrm{C}$ during the coldest week. The minimum temperature during winter can reach 2 ${ }^{\circ} \mathrm{C}$. Fig. 1a shows the monthly statistics for the evolution of the dry bulb temperatures in Kuwait, and Fig. 1b shows 
the average hourly statistics for global horizontal solar irradiation during August, where the extreme summer weak is verified. More statistics information about the climate of Kuwait can be found in the KISR Kuwait Intl Airport KWT weather data file (EnergyPlus 8.0.0 2014).

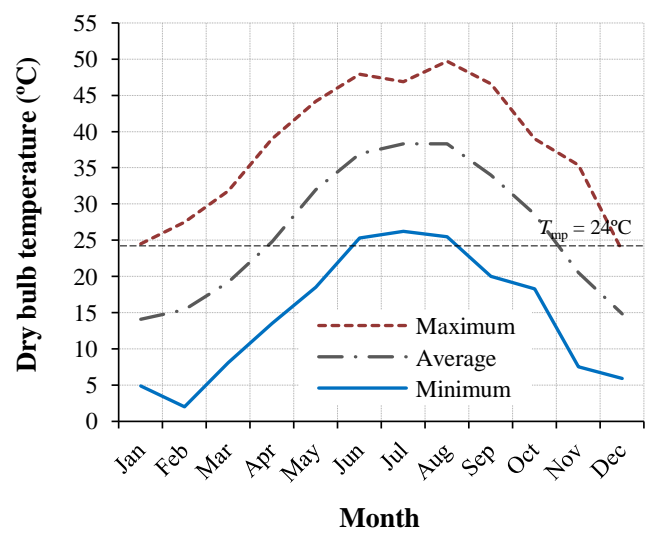

(a)

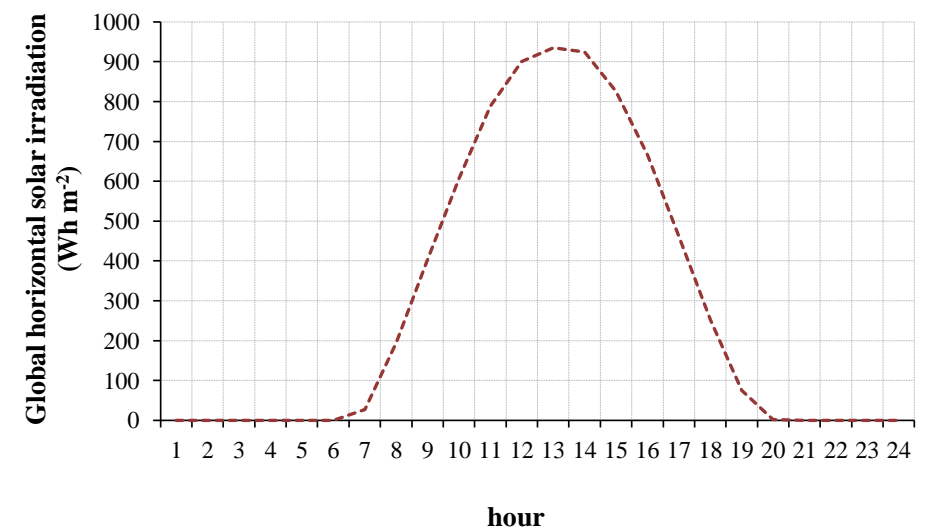

(b)

Fig. 1. (a) Monthly statistics for the evolution of the dry bulb temperatures in Kuwait and (b) average hourly statistics for global horizontal solar irradiation during August (KISR Kuwait Intl Airport - KWT weather data (EnergyPlus 8.0.0 2014)).

Some internal loads and six window-to-wall ratios (WWR) of the main solar oriented window facade are considered in the study. The energy impact of incorporating seven different PCM-wallboards in the model is then evaluated in order to understand whether a single, fully-customized PCM-wallboard solution exists that could be universally used in residential construction in Kuwait. The motivation for searching for a single solution is to benefit from economy of scale effects and to facilitate smooth implementation. A set of discrete variables is considered in the parametric study, namely those related with the thermophysical properties of the PCM (enthalpy-temperature and thermal conductivity-temperature functions) and thickness of the PCM-wallboard. In order to evaluate the influence of the cooling setpoint temperature $\left(T_{\mathrm{th}}\right)$ of the air-conditioning system in the selection of the fullycustomized PCM-wallboard solution, five values of $T_{\text {th }}$ are considered in the study.

\subsection{Reference model}

As shown in Fig. 2, 28 fully air-conditioned single-zone models with seven WWRs facing the four cardinal directions were considered. The interior air volume remains as specified in ASHRAE 140 standard (ANSI/ASHRAE 2004) - interior dimensions of $8 \mathrm{~m} \times 6 \mathrm{~m} \times 2.7 \mathrm{~m}=129.6 \mathrm{~m}^{3}$. The models were assumed to have their windows concentrated on one side to reflect current, relatively dense, deep floor plan residential construction practices in Kuwait in which most spaces only have windows with one orientation. The total floor area of the room is $48 \mathrm{~m}^{2}$ with 
a slab-on-grade foundation. All vertical surfaces are considered as external walls. The model is not obstructed by neighboring buildings and the ground reflectance is equal to 0.2. Table 1 shows the specific glazing types for different WWR values in accordance with the requisites of the building energy code of Kuwait (Ministry of Electricity and Water 2010). The different WWRs are obtained by changing the fenestration area as shown in Fig. 2. Table 1 shows that the higher the value of the WWR, the more selective the requirements of the glazing type, with lower $U$ and SHGC values. This is a way to prevent the boost of cooling energy demand when increasing the fenestration area.

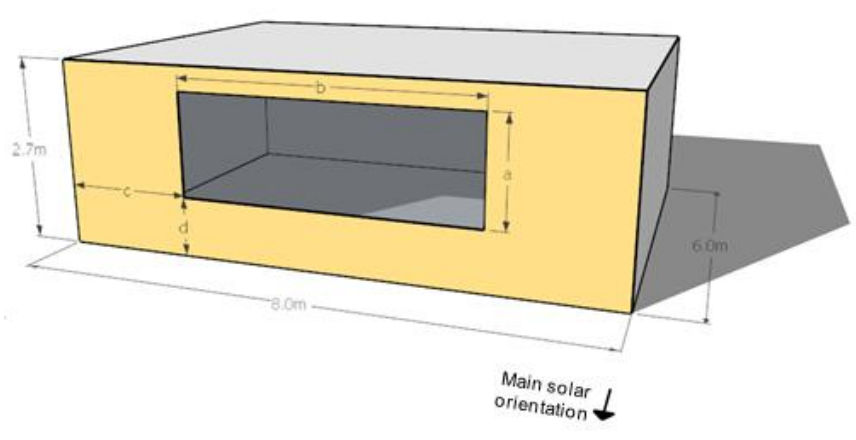

\begin{tabular}{|c|c|c|c|c|c|}
\hline & Room - WWR & & & & \\
\hline & & $\mathrm{a}(\mathrm{m})$ & $\mathrm{b}(\mathrm{m})$ & $\mathrm{c}(\mathrm{m})$ & $\mathrm{d}(\mathrm{m})$ \\
\hline$\square$ & R1 $-10 \%$ & 1.00 & 2.16 & 2.92 & 1.35 \\
\hline$\square$ & R2 - $20 \%$ & 1.00 & 4.32 & 1.84 & 1.35 \\
\hline & R3 - 30\% & 1.50 & 4.32 & 1.84 & 0.85 \\
\hline  & R4 - 40\% & 1.50 & 5.76 & 1.12 & 0.85 \\
\hline & R5 - 50\% & 2.00 & 5.4 & 1.3 & 0.35 \\
\hline & R6 - $60 \%$ & 2.00 & 6.48 & 0.76 & 0.35 \\
\hline & R7 - 70\% & 2.00 & 7.56 & 0.22 & 0.35 \\
\hline
\end{tabular}

Fig. 2. Perspective view of the reference room and window-to-wall ratio layouts of the main solar oriented facade.

Table 1. Different types of glazing for different WWR in accordance with the building energy code of Kuwait (Ministry of Electricity and Water 2010).

\begin{tabular}{cccc}
\hline WWR $(\boldsymbol{\%})$ & Glazing type required & $\boldsymbol{U}\left(\mathbf{W} \mathbf{~ m}^{-\mathbf{2}} \mathbf{C}^{\mathbf{- 1}}\right)$ & $\boldsymbol{S H G C}$ \\
\hline 10 & 6-mm double-tinted & 3.42 & 0.360 \\
20 & 6-mm double-reflective & 3.38 & 0.245 \\
30 & 6-mm double-reflective & 3.38 & 0.245 \\
40 & 6-mm double-reflective & 3.38 & 0.245 \\
50 & 6-mm double-spectrally selective & 1.71 & 0.230 \\
60 & 6-mm double-spectrally selective & 1.71 & 0.230 \\
70 & 6-mm double-spectrally selective & 1.71 & 0.230 \\
\hline
\end{tabular}

In their work, (Al-ajmi and Hanby 2008) describe the typical Kuwaiti residential building. According to them, the traditional flat roof is almost universal in Kuwait and the exterior walls are mainly built of two types: autoclaved aerated concrete (AAC) walls and concrete block walls (the so called "classical wall"). The latter type is cheaper (if no insulation is added), widely available, locally produced and structurally stronger than AAC. It is also widely accepted by the buildings industry, and the appropriate-skilled manpower for its construction is available (Al-ajmi and Hanby 2008). The AAC has the advantage of also acting as thermal insulation, but there are few factories producing these blocks locally and their price is higher (Al-ajmi and Hanby 2008). Given these constraints, for the purpose of this study, the classical wall typology will be considered in the simulations. Fig. 3 shows a cross- 
section of the reference construction elements used and Table 2 lists the thermophysical properties of the underlying materials. The reference $U$-value for each element is considered equal to the corresponding maximum $U$-value specified in the regulation (for heavy construction and medium-light external color) (Ministry of Electricity and Water 2010), i.e., $0.568 \mathrm{~W} \mathrm{~m}^{-2}{ }^{\circ} \mathrm{C}^{-1}$ for the walls and $0.397 \mathrm{~W} \mathrm{~m}^{-2}{ }^{\circ} \mathrm{C}^{-1}$ for the roof. Changes in the $U$-value of the construction elements can be achieved by varying the thickness of the insulation layers $t c k_{\text {ins,wall }}$ and $t c k_{\text {ins,roof. For the }}$ reference rooms, the thickness of the insulation layer is equal to $4.5 \mathrm{~cm}$ and $6.0 \mathrm{~cm}$ for the wall and roof, respectively. The solar absorption coefficient was about 0.6 for the horizontal outer opaque surfaces, and 0.4 for the vertical surfaces.

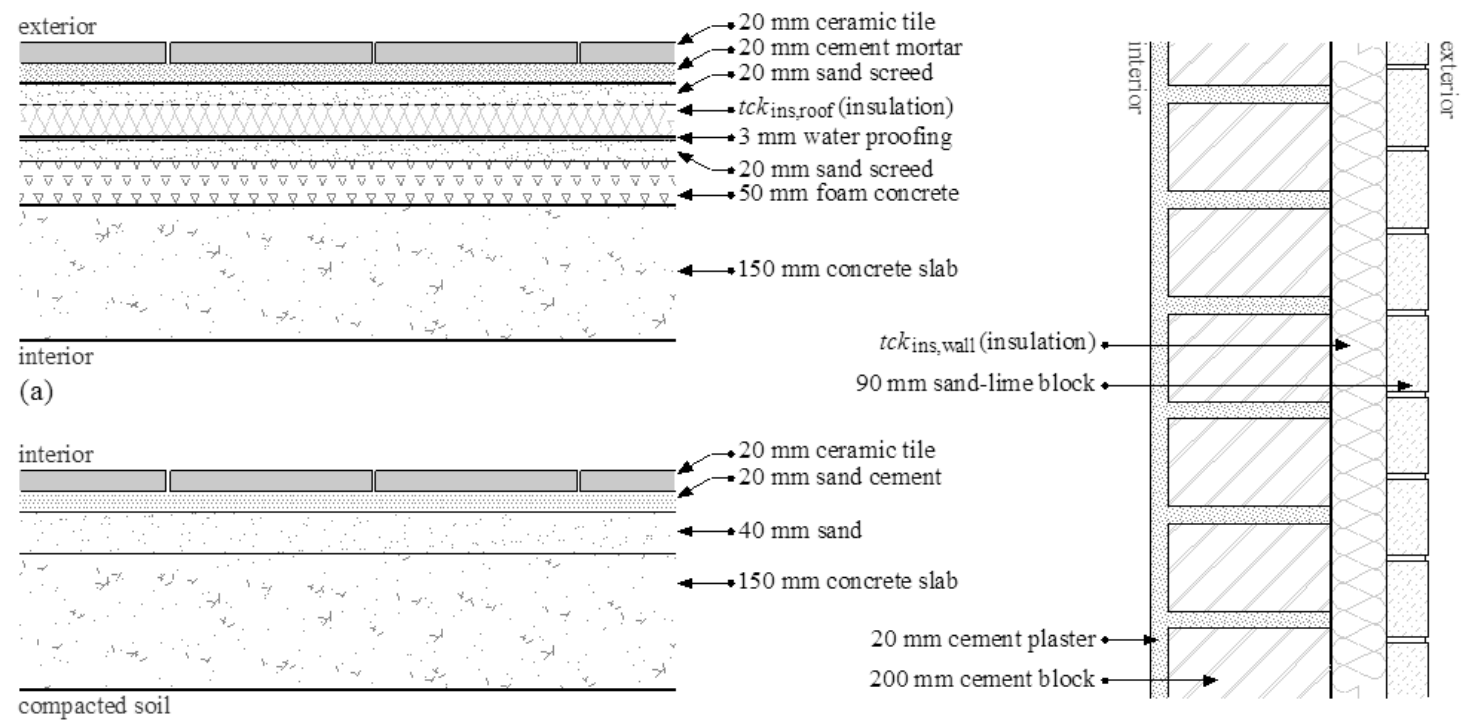

(b)

Fig. 3. Cross-section of the construction elements used in the model: (a) roof; (b) floor, and (c) exterior wall (adapted from (Al-ajmi and Hanby 2008)).

Table 2. Thermophysical properties of the construction materials (Al-ajmi and Hanby 2008).

\begin{tabular}{lrrr}
\hline \multicolumn{1}{c}{ Material } & $\boldsymbol{k}\left(\mathbf{W ~ m}^{\mathbf{- 1}}{ }^{\mathbf{o}} \mathbf{C}^{\mathbf{- 1}}\right)$ & $\boldsymbol{c}_{\boldsymbol{p}}\left(\mathbf{J ~ k g}^{-\mathbf{1}} \mathbf{K}^{\mathbf{- 1}}\right)$ & $\boldsymbol{\rho}\left(\mathbf{k g ~ m}^{\mathbf{- 3}}\right)$ \\
\hline Sand-lime block & 1.310 & 795 & 1918 \\
Cement block & 1.640 & 910 & 2011 \\
Cement plaster & 0.944 & 840 & 2085 \\
Cement mortar & 0.944 & 840 & 2085 \\
Concrete slab & 1.214 & 921 & 2297 \\
Foam concrete & 0.210 & 879 & 351 \\
Sand cement & 0.944 & 840 & 2080 \\
Sand screed & 0.944 & 840 & 2080 \\
Sand & 0.337 & 920 & 1800 \\
Ceramic tile & 1.104 & 800 & 2284 \\
Insulation & 0.032 & 1120 & 30 \\
Water proofing & 0.140 & 1507 & 934 \\
\hline
\end{tabular}

Regarding internal heat gains, the building model is occupied by a maximum of 4 people in sedentary activity with a constant metabolic rate of about 1.2 met $\left(126 \mathrm{~W}\right.$ person $\left.{ }^{-1}\right)$. During the Sunday-Thursday $8 \mathrm{am}-4 \mathrm{pm}$ 
weekdays hours, only 1 of the assumed 4 persons occupies the space. During the weekdays and weekends, from 1am to $6 \mathrm{am}$, only 1 person is assumed to occupy the space. The remaining periods are considered at $100 \%$ occupancy. A maximum design lighting level of $10 \mathrm{~W} \mathrm{~m}^{-2}$ is considered in the model (Ministry of Electricity and Water 2010). The maximum load of $8 \mathrm{~W} \mathrm{~m}^{-2}$ is considered for equipment. Fig. 4 shows the occupancy, lighting and equipment schedules during the week. The room is air-conditioned considering an ideal loads air system model in the EnergyPlus simulations. Regarding air temperature control, the thermostat is set with a cooling setpoint temperature of $24^{\circ} \mathrm{C}$. A ventilation rate of 0.5 air changes per hour is considered in the model (Ministry of Electricity and Water 2010).
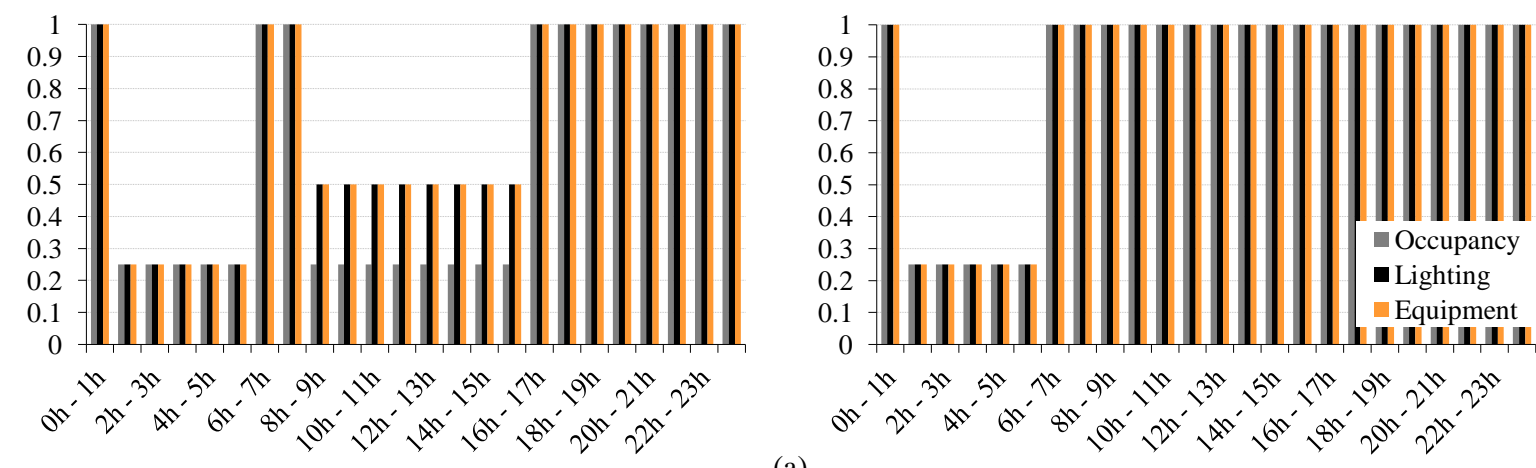

(a)

Fig. 4. Occupancy, lighting and equipment schedules during (a) Sunday-Thursday weekdays and (b) Friday-

Saturday weekends.

\subsection{Problem description and design variables}

The monthly and annual cooling energy demands are determined for each reference model without PCM-wallboards and then compared through simulation with the monthly and annual cooling energy demands of the correspondent PCM-enhanced model. The one-dimensional conduction finite-difference (CondFD) solution algorithm, which was validated against multiple test suites (analytical verification, comparative testing, and empirical validation) by (Tabares-Velasco et al. 2012) was used in EnergyPlus 8.3 to simulate phase-change processes. It is an implicit finite difference scheme coupled with an enthalpy-temperature function to account for phase-change energy accurately. These authors stated that the default CondFD model (Fourier number $F o=1 / 3$ and space discretization constant $c=$ 3) can be used with acceptable monthly and annual results, but a smaller node space should be used if accurate hourly analysis is required. In this study, the default CondFD model with 20 time steps per hour is used for assessing the monthly and annual cooling energy demand, for both the reference and the PCM-enhanced models. For the hourly analysis, the CondFD model is used with the node space equal to $1 / 3$ of the default value as suggested by (Tabares-Velasco et al. 2012). The CondFD model neither simulates hysteresis of the PCM nor does it simulate 
subcooling during discharging, and only the enthalpy-temperature information for the heating mode is given by the user. Therefore, accuracy issues can arise when modeling PCMs with strong hysteresis or subcooling. For the purpose of this study, the hysteresis and the subcooling phenomena are not considered in the simplified model.

The PCM-enhanced model is attained by including a PCM-wallboard on the inner surface of the walls and ceiling of the reference model. Afterwards, a parametric analysis is carried out by varying the thickness of the PCMwallboard and the melting-peak temperature of the PCM. In the parametric analysis, all the design solutions are specified as discrete independent variables that can only take predefined discrete values. The DuPontTM Energain ${ }^{\circledR}$ PCM product was considered as the reference PCM-wallboard. This material has a melting temperature range centered around $21.7{ }^{\circ} \mathrm{C}$, latent heat of $70 \mathrm{~kJ} \mathrm{~kg}^{-1}$, density of $855 \mathrm{~kg} \mathrm{~m}^{-3}$, specific heat of $2500 \mathrm{~J} \mathrm{~kg}^{-1} \mathrm{~K}^{-1}$ and a variable thermal conductivity (Tabares-Velasco et al. 2012). As proposed by (Soares et al. 2014) and (TabaresVelasco 2012), based on the nonlinear enthalpy-temperature function of a reference material, a new linear function can be plotted for an hypothetical PCM-wallboard to facilitate the parametric analysis. The new material will have a melting range between 18 and $26{ }^{\circ} \mathrm{C}$ centered around $22{ }^{\circ} \mathrm{C}$. (Tabares-Velasco 2012) concluded that the annual energy demand is not particularly sensitive to the linearization of the enthalpy-temperature curve. However, for hourly analysis, the simpler linear profiles should be specified in a way that the melting range covers roughly $80 \%$ of the latent heat, otherwise, results can differ by up to $20 \%$ (Tabares-Velasco 2012).

In this study, further six hypothetical PCM-wallboards with the same latent heat characteristics but with different melting ranges centered at different melting-peak temperatures are defined. Therefore, seven PCMwallboards with melting-peak temperatures $\left(T_{\mathrm{mp}}\right)$ of about $18,20,22,24,26,28$ and $30^{\circ} \mathrm{C}$ are considered in the parametric study. Figs. 5a and 5b show, respectively, the enthalpy-temperature and the thermal conductivitytemperature functions for the reference PCM-wallboard and for the other seven hypothetical materials defined. In the developed model, the thermal conductivity is considered different for the solid and liquid phases but it varies linearly with temperature during phase change (Fig. 5b). The variable thermal conductivity of the reference material was plotted using the information provided by (Tabares-Velasco et al. 2012). Afterwards, new 7 evolutions of the thermal conductivity with the variation of temperature were defined as shown in Fig. $5 b$ (one curve for each one of the hypothetical material defined). The thickness of the PCM-wallboard ( $t c k_{\mathrm{PCM}}$ ) can be equal to 1.0, 1.5, 2.0, 2.5, 3.0, 3.5 and $4.0 \mathrm{~cm}$. Regarding the combination of all the referred values, a set of 49 predefined discrete solutions can be considered for comparison with the reference model for each orientation of the window and for each WWR considered. 


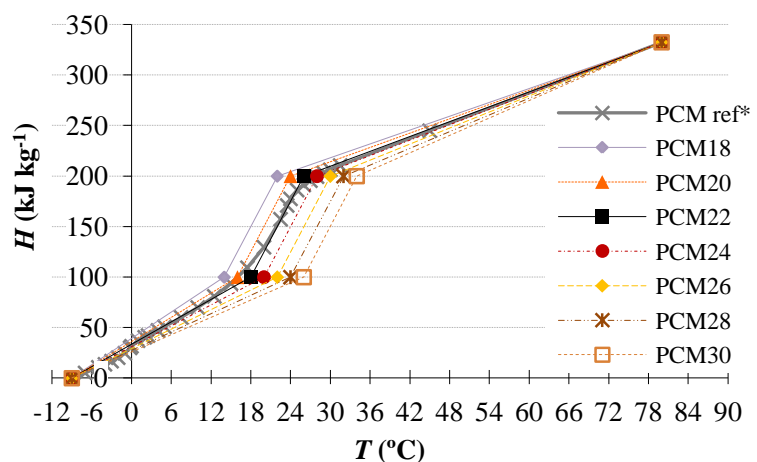

(a)



(b)

Fig. 5. (a) Enthalpy-temperature and (b) thermal conductivity-temperature functions for the reference PCMwallboard and other seven hypothetical materials. *Data for DuPont ${ }^{\mathrm{TM}}$ Energain ${ }^{\circledR} \mathrm{PCM}$ product obtained from differential scanning calorimeter (DSC) measurements with a heating rate of $0.05^{\circ} \mathrm{C} \min ^{-1}$ (Cao et al. 2010).

\section{Results and discussion}

\subsection{Annual assessment basis - reference rooms and fully-customized PCM-wallboard solution}

The index of annual energy savings for cooling $\left(I E S C_{\mathrm{a}}\right)$ is used for quantifying the reduction of the energy demand for cooling and to evaluate the energy performance of the PCM-enhanced room. It is defined by:

$$
I_{E S C}=1-E_{\mathrm{cool}, \mathrm{PCM}, i} / E_{\mathrm{cool}, \mathrm{ref}, i} \times 100 \% .
$$

Subscript $i$ refers to the assessment time period. Subscripts $a$ and $m$ correspond to the annual and monthly assessment basis, respectively. Fig. 6 shows the annual energy demand for cooling for the PCM-enhanced room facing West with WWR $=10 \%$ for different melting-peak temperatures and PCM thicknesses. The figure reveals that the best PCM-wallboard for this configuration is the one with $T_{m p}=24^{\circ} \mathrm{C}$ and the highest possible thickness considered, namely $4 \mathrm{~cm}$. For the same PCM-wallboard - PCM24, annual cooling energy savings of about $3.3 \%$ can be achieved by changing the thickness of the wallboard from $1 \mathrm{~cm}$ to $4 \mathrm{~cm}$. The results obtained in the parametric study by combining different WWR-values and solar orientations were similar to those presented in Fig. 6, i.e. the best solution for all the case-studies is the $4 \mathrm{~cm}$ thick PCM-wallboard with $T_{\mathrm{mp}}=24^{\circ} \mathrm{C}$. An interesting feature is that the best value of the melting-peak temperature of the PCM is equal to the air-conditioning thermostat setpoint temperature for cooling. For $T_{\mathrm{mp}}$ values close to $24^{\circ} \mathrm{C}$, i.e., $22^{\circ} \mathrm{C}$ and $26^{\circ} \mathrm{C}$, the results achieved are very similar. For melting-peak temperatures of $28{ }^{\circ} \mathrm{C}$ and $30^{\circ} \mathrm{C}$, and for the same mass of material, the energy required for cooling is higher. The same trend is verified for $T_{\mathrm{mp}}=18^{\circ} \mathrm{C}$.

The EnergyPlus-based simulations show that $4 \mathrm{~cm}$ is the optimal thickness for the PCM-wallboard regarding energy savings (Fig. 6). However, in practical applications, it may be a good compromise to adopt $2 \mathrm{~cm}$ instead of $4 \mathrm{~cm}$ thick as the energy savings achieved with $2 \mathrm{~cm}$ are very close to those obtained with $4 \mathrm{~cm}$. This 
could be particular important if we take into account the cost of the PCM-wallboards, where the thickness of the wallboards may have a strong impact. Moreover, the majority of PCM-wallboards available on the marked have typically small thicknesses because of the low thermal conductivity of PCMs. In practical applications, thinner PCM-wallboards may work better as more PCM material would be involved in the phase change. However, for the purpose of this study, the best $4 \mathrm{~cm}$ thick solution regarding energy savings (Fig. 6) will be considered in the next sections.

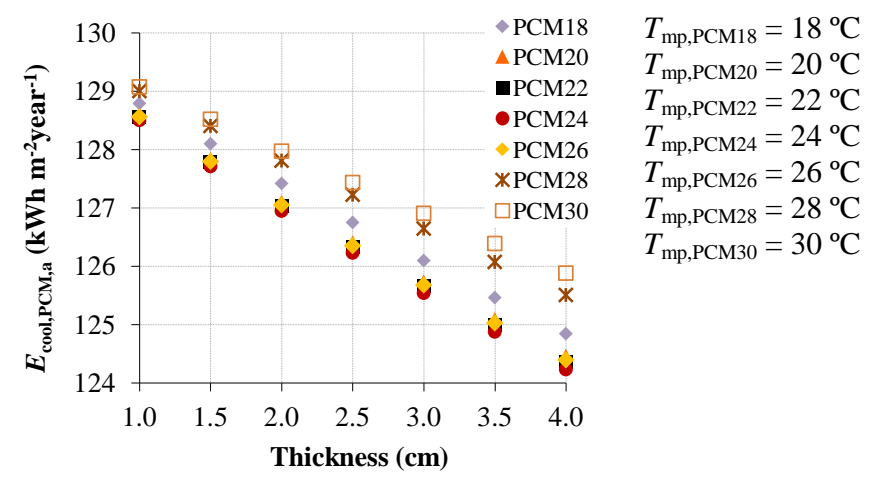

Fig. 6. Annual cooling energy demand for the PCM-enhanced room with WWR $=10 \%$ facing West and $T_{\text {th }}=24^{\circ} \mathrm{C}$ considering different melting-peak temperatures and PCM-wallboards thicknesses.

Fig. 7 shows the annual energy demand for cooling for all the reference scenarios. As one would expect, the results show that the higher the WWR, the higher the annual energy demand for cooling. When the WWR increases from $10 \%$ to $70 \%$, considering the West-oriented room, the annual cooling energy demand increases by $20 \%$. This value is about $16 \%, 17 \%$ and $9 \%$, respectively, for the remaining East, South and North orientations. Windows facing West lead to the highest solar heat gains, while windows facing North receive the least amount of solar radiation, becoming preferable for the climate of Kuwait. It should be noted that the increasingly stringent glazing type specifications required by the Kuwaiti building code (Table 1) (Ministry of Electricity and Water 2010) with growing WWR effectively mitigate the boost in cooling energy demand. If the same 6-mm double-tinted glazing type was used for West-oriented room with a 70\% WWR, annual cooling demand would increase by $36 \%$ instead of $20 \%$ (considering the 6-mm double-spectrally selective glazing type). Fig. 7 shows that the reduction of the annual energy demand for cooling (by incorporating the fully-customized $4 \mathrm{~cm}$ thick PCM24-wallboard solution in the reference models) can reach $4 \%$ to $5 \%$ in all the scenarios (5.5 to $\left.6.6 \mathrm{kWh} \mathrm{m}^{-2} \mathrm{year}^{-1}\right)$. 


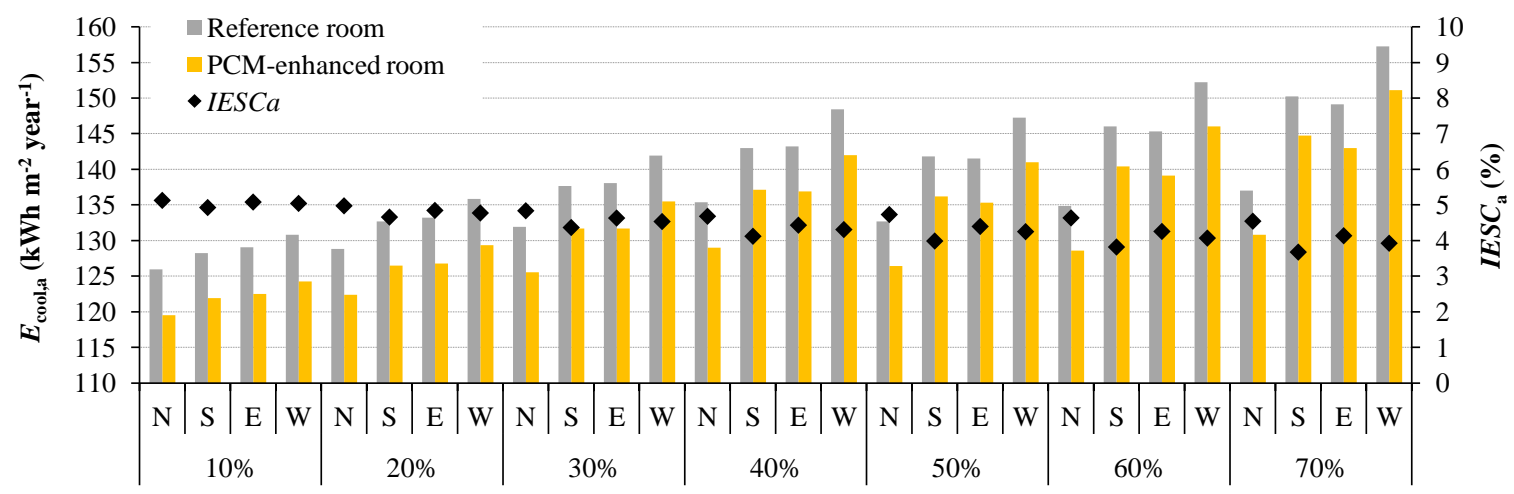

WWR and Solar orientation of the glazing facade

Fig. 7. Annual cooling energy demand for all the reference and PCM-enhanced models considering $T_{\mathrm{th}}=24^{\circ} \mathrm{C}$. Index of annual energy savings for cooling by considering the incorporation of the fully-customized PCM-wallboard solution in the reference rooms.

\subsection{Annual assessment basis - impact of the cooling setpoint temperature}

The results shown in the previous section may suggest that the best melting-peak temperature of the PCM incorporated in the PCM-wallboard is equal to the imposed cooling setpoint temperature of the air-conditioning system. In order to evaluate the impact of the $T_{\mathrm{th}}$-value on the results, the same analysis carried out in section 3.1 is repeated by considering $T_{\text {th }}$ equal to $18,20,22$ and $26^{\circ} \mathrm{C}$.

The bullets on the graph of Fig. 8 show the best value of $T_{\mathrm{mp}}$ for different values of $T_{\mathrm{th}}$ and for all the casestudies evaluated in the parametric study (read the value of $T_{\mathrm{mp}, \mathrm{opt}}$ on the right axis). Additionally, Fig. 8 shows the absolute annual energy savings for cooling (read on the left axis) by incorporating the best PCM-wallboard solution for each scenario (with $T_{\mathrm{mp}}=T_{\mathrm{mp}, \mathrm{opt}}$ ) in the simulations. Therefore, the absolute annual energy savings for cooling are presented as a function of the orientation of the window and the values of WWR and $T_{\mathrm{th}}$. Results show that for $T_{\text {th }}=26^{\circ} \mathrm{C}$, the best melting-peak temperature of the PCM is also equal to $T_{\text {th }}$. However, for $T_{\text {th }}=18{ }^{\circ} \mathrm{C}$ and $20^{\circ} \mathrm{C}$, the best values of $T_{\mathrm{mp}}$ are $20^{\circ} \mathrm{C}$ and $22^{\circ} \mathrm{C}$, respectively. Generally speaking, for $T_{\mathrm{th}}=22^{\circ} \mathrm{C}$, the best $T_{\mathrm{mp}}$ is $22^{\circ} \mathrm{C}$ for lower values of WWR and $24{ }^{\circ} \mathrm{C}$ for higher values of the same parameter. These results can be used as guidelines for the incorporation of PCM-wallboards in Kuwait. 


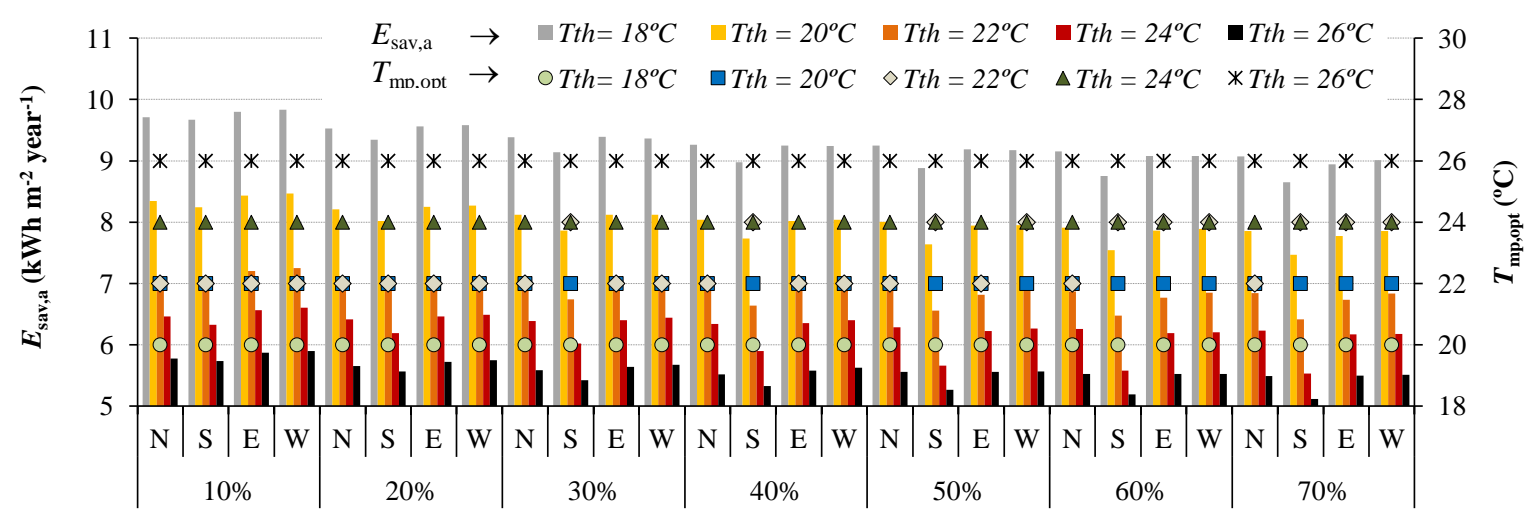

WWR and Solar orientation of the glazing facade

Fig. 8. Best value of $T_{\mathrm{mp}}$ for different values of $T_{\mathrm{th}}$ and for all the case-studies investigated in the parametric analysis (read the value of $T_{\mathrm{mp}, \mathrm{opt}}$ on the right axis). Annual absolute cooling energy savings (read on the left axis) by incorporating the best PCM-wallboard solution for each scenario (with $T_{\mathrm{mp}}=T_{\mathrm{mp}, \mathrm{opt}}$ ) in the simulations.

Regarding the annual cooling savings by incorporating PCM-wallboards in the model, Fig. 8 shows that, in absolute terms, the lower the value of $T_{\text {th }}$, the higher the energy savings. However, in relative terms, i.e., by evaluating the IESCa values, the lower the value of $T_{\mathrm{th}}$, the lower the relative cooling energy savings as shown in Fig. 9. This is caused by the fact that the reference energy demand for cooling is higher for lower values of $T_{\mathrm{th}}$. Therefore, a setpoint temperature of the air-conditioning system close to $22-24^{\circ} \mathrm{C}$ can be a good compromise for reducing the energy consumption for cooling in Kuwait. In the next sections, the cooling setpoint temperature will be considered fixed at $24{ }^{\circ} \mathrm{C}$ as described in section 2.1 .

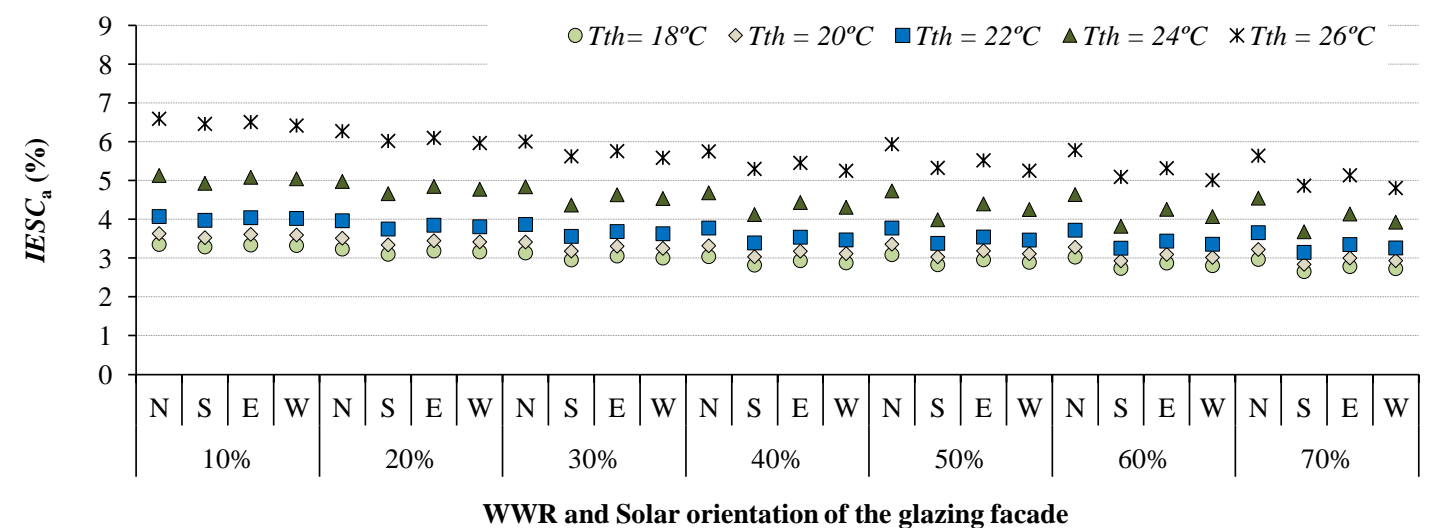

Fig. 9. Index of annual energy savings for cooling for all the case-studies investigated in the parametric study by considering the incorporation of the best PCM-wallboard solution for each scenario (with $T_{\mathrm{mp}}=T_{\mathrm{mp}, \mathrm{opt}}$ ) in the simulations.

\subsection{Annual assessment basis - Economic assessment}


In this section, the economic viability of the incorporation of PCM-wallboards in Kuwait is discussed. The nominal annual savings of useful energy for cooling after the incorporation of the best PCM-wallboard solution in each simulated scenario will be used to estimate the payback period of the PCM-enhanced solution. In the economic assessment, only the initial cost of the PCM-wallboard technology is considered. The costs related to the application and maintenance of the PCM-enhanced boards are not considered in the study.

The cost of a specific PCM-wallboard solution, with certain thermophysical properties and thickness, is difficult to estimate, as the solution may not be available on the market. However, the effort to predict the payback period of a specific PCM-wallboard solution for the climate of Kuwait can be seen as a good approach to foster the implementation of the technology in the country. Table 3 shows the price of some ordinary and PCM-enhanced wallboards available on the market. It can be seen that the price of the wallboards depends on their thickness and the proportion of incorporated PCMs. It can also be estimated that, PCM-wallboards can be 5-16 times more expensive than ordinary wallboards, which is in accordance with literature (Fraser 2009).

Table 3. Price of some ordinary and PCM-enhanced wallboards available on the market.

\begin{tabular}{|c|c|c|c|c|}
\hline & Product & Thickness (mm) & Price $\left(€ / \mathrm{m}^{2}\right)$ & Source \\
\hline PCM-wallboards & $\begin{array}{l}\text { Dupont }^{\mathrm{TM}} \text { Energain }^{\circledR} \\
\text { Datum phase change F.E.S-Board }\end{array}$ & $\begin{array}{c}6 \\
25\end{array}$ & $\begin{array}{c}69.00 \\
35-104 \\
\text { Depending on the } \\
\text { proportion of PCM in the } \\
\text { board }\end{array}$ & $\begin{array}{c}\text { (Fraser 2009) } \\
\text { (Rae 2014; } \\
\text { Pullen 2012) }\end{array}$ \\
\hline \multirow[t]{3}{*}{ Ordinary drywalls } & Gyptec Ibérica BA 6 A & 6 & 5.03 & $\begin{array}{c}\text { (Gyptec } \\
\text { Ibérica 2016) }\end{array}$ \\
\hline & Gyptec Ibérica BA 10 A & 10 & 3.51 & $\begin{array}{c}\text { (Gyptec } \\
\text { Ibérica 2016) }\end{array}$ \\
\hline & Gyptec Ibérica BA 13 A & 12.5 & 3.25 & $\begin{array}{c}\text { (Gyptec } \\
\text { Ibérica 2016) }\end{array}$ \\
\hline
\end{tabular}

For the purpose of this study, a hypothetical price of $140 € / \mathrm{m}^{2}$ will be considered for the fully-customized 4 cm thick PCM24-wallboard solution. Regarding utility charges in Kuwait, the cost of electricity is about $\approx 0.11$ $€ / \mathrm{kWh}$ (Ministry of Electricity and Water). However, it should be pointed out that this cost is highly subsidized and the building owners only pay $\approx 0.01 € / \mathrm{kWh}$ (flat fixed rate). Considering the cost of electricity of about $0.11 € / \mathrm{kWh}$ and the energy savings for cooling due to the incorporation of PCM-wallboards in the model, for an Energy Efficiency Ratio (EER) of the cooling system of 2, the estimated payback period for the incorporation of the $4 \mathrm{~cm}$ thick PCM24-wallboard solution in all the scenarios is higher than the lifespan period of the building ( $>50$ years). These results suggest that under current economic conditions in Kuwait, PCM-wallboards are not economically viable for heavyweight construction. The reasons for this finding are the remarkably low subsidized price of electricity along with an already high thermal mass construction standard that benefits less from adding PCMs. 


\subsection{Monthly assessment basis}

In this section, the impact of the fully-customized $4 \mathrm{~cm}$ thick PCM24-wallboard solution on the energy demand throughout the year is investigated. Figs. 10a and 10b show the monthly cooling energy demand for both the reference and the PCM-enhanced models with $\mathrm{WWR}=10 \%$ and $70 \%$, respectively. The same trends were verified for the remaining five scenarios investigated in the parametric study. Fig. 10 shows that the cooling demand is naturally higher during the summer months. During this period, the relative monthly energy savings for cooling due to PCMs can reach 5\% to 7\% (read the value of $I E S C_{\mathrm{m}}$ on the right axis). Therefore, it can be seen that PCMs may be relevant as a means to the summer cooling peaks. Another interesting feature is that the energy demand for cooling during the winter months increases by incorporating PCM-wallboards in the model $\left(I E S C_{\mathrm{m}}\right.$ presents negative values). However, the absolute amount of energy required for cooling during the cold months is practically negligible when compared with the summer period. Fig. 11 summarizes the reduction of the monthly cooling load during the month with the highest average cooling load for each case-study evaluated. The results show that the monthly cooling loads can be reduced by $5 \%$ to $6 \%$ in all the scenarios.



Month and solar orientation of the glazing facade $-\mathrm{WWR}=10 \%$

(a)

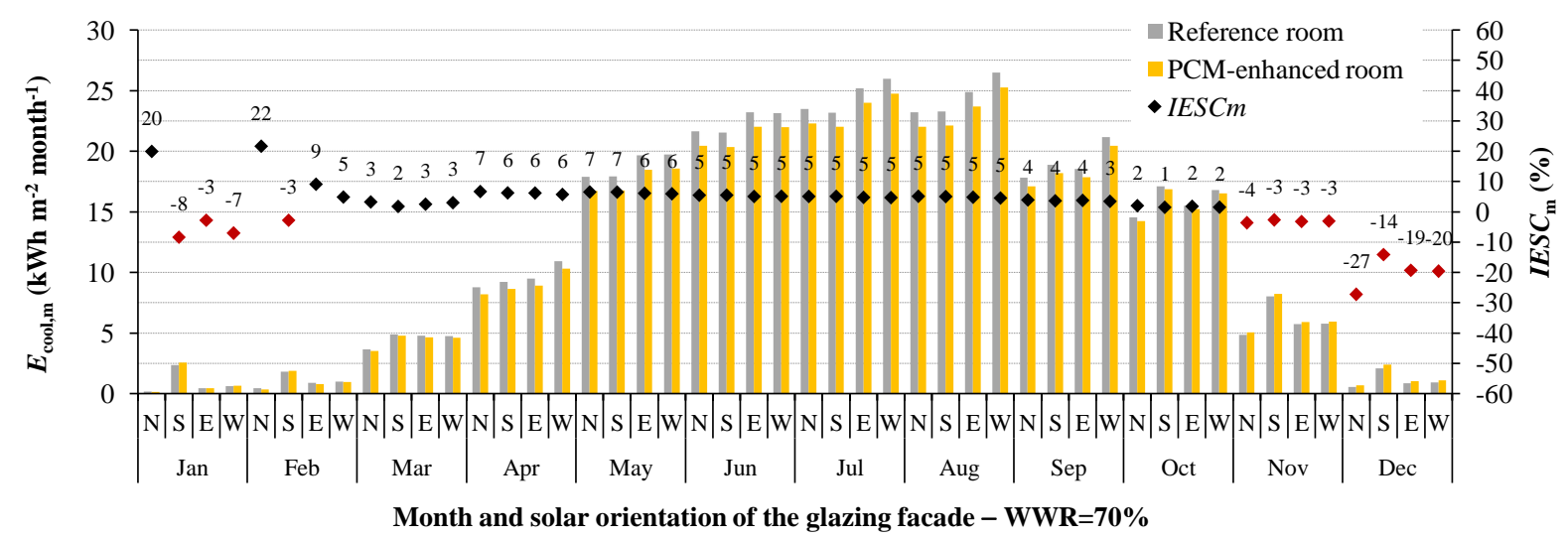

(b)

Fig. 10. Monthly cooling energy demand for both the reference and the PCM-enhanced rooms with (a) WWR = $10 \%$, and (b) WWR $=70 \%$. Index of monthly energy savings for cooling considering the incorporation of the $4 \mathrm{~cm}$ thick PCM24-wallboard solution in the model and $T_{\mathrm{th}}=24^{\circ} \mathrm{C}$. 


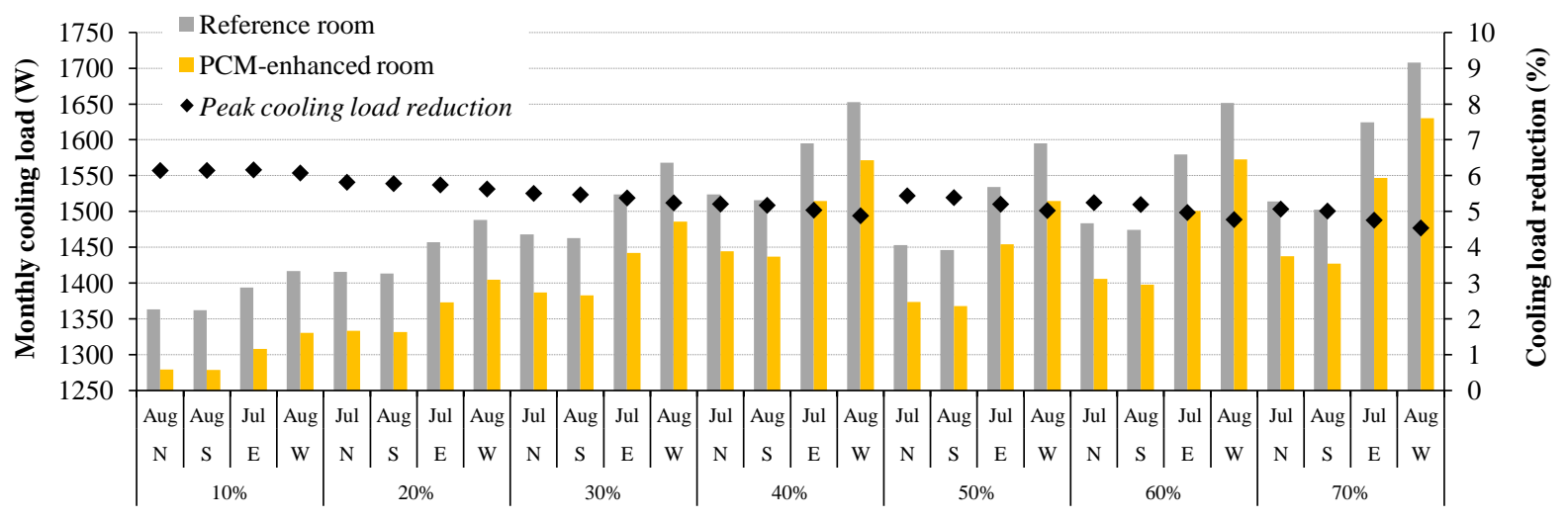

WWR, solar orientation of the glazing facade and month with higher cooling energy demand

Fig. 11. Reduction of the monthly cooling load during the month with the highest average cooling load for all the case-studies considering $T_{\mathrm{th}}=24^{\circ} \mathrm{C}$.

\subsection{Daily assessment basis}

As it was remarked in the introduction section, the summer cooling peak hours are problematic in Kuwait, with the danger of recurring electricity blackouts during this period. In this section, the impact of incorporating the fullycustomized $4 \mathrm{~cm}$ thick PCM24-wallboard solution in the model is investigated in a daily assessment basis. The final idea is to evaluate how the incorporation of PCM-wallboards influences the thermal performance of the model if the air-conditioning system was turned off during the summer peak hours. The hourly evolution of the indoor air temperature $\left(T_{\mathrm{a}}\right)$, mean radiant temperature $\left(T_{\mathrm{mr}}\right)$ and operative temperature $\left(T_{\mathrm{o}}\right)$ will also be evaluated for the day with the highest average daily cooling load - the $5^{\text {th }}$ of August. Fig. 12 summarizes the reduction of the average daily cooling load for all the case-studies (5\% to $8 \%$ ) for this day. The results show that the average daily cooling load can be reduced by 107 to $131 \mathrm{~W}$.

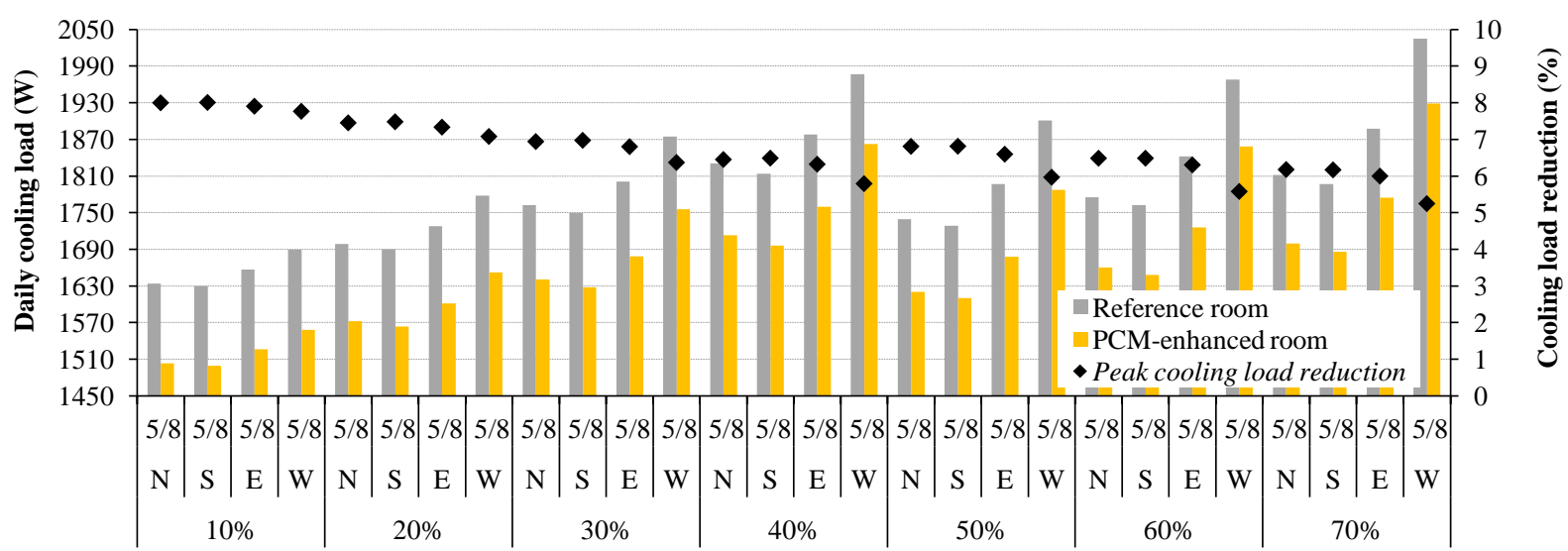

WWR, solar orientation of the glazing facade and peak cooling day/month

Fig. 12. Reduction of the average daily cooling load for the $5^{\text {th }}$ of August, for all the case-studies evaluated and by considering $T_{\mathrm{th}}=24^{\circ} \mathrm{C}$. 
Fig. 13 shows the cooling profiles in an hourly assessment basis for the cooling peak day, for both the reference and the PCM-enhanced models with WWR $=10 \%$ and $70 \%$, respectively. The evolutions of $T_{\mathrm{a}}, T_{\mathrm{mr}}$ and $T_{\mathrm{o}}$ are also shown. The results show that the maximum cooling load of $\approx 3300 \mathrm{~W}$ is estimated for the West-oriented model with WWR $=70 \%$, between $6 \mathrm{pm}$ and $7 \mathrm{pm}$. The incorporation of the fully-customized $4 \mathrm{~cm}$ thick PCM24wallboard solution reduces the cooling load profiles for all the scenarios. An exception is the West-oriented room with WWR $=70 \%$, where PCMs can increase the cooling loads during the peak hours.

Many times, the daily cooling profiles are simulated considering the PCMs completely discharged at the beginning of the day. In these cases, the reduction of the cooling loads is higher (with a significant delay of the peak hour) because more volume of PCM will be melted during the day and more latent heat will be stored. However, in real applications, mainly during the severe summer conditions of Kuwait, the PCM can be completely melted at the beginning of the summer peak day-cycle, which reduces the PCM capacity for latent heat storage. Moreover, large West-oriented windows are a major source of solar heat gains during the last sun-hours of the day, a period when the internal heat gains from occupancy, lighting and equipments also increase. Consequently, there is a boost in the energy demand for cooling, with no help from the latent heat loads from PCMs' phase-change processes, as they are completely melted at this time. In the East oriented rooms, a cooling peak is observed during the morning, which is caused by the morning solar heat gains and by the internal heat gains during these hours. Generally speaking, the cooling peak-loads are observed during the summer electricity demand peak hours, from $2 \mathrm{pm}$ to $4 \mathrm{pm}$, which is problematic for the management of the energy supply in Kuwait.

Regarding the evolution of the temperature profiles during the cooling peak day, it is interesting to observe that $T_{\mathrm{mr}}$ is reduced by almost $1{ }^{\circ} \mathrm{C}$ in most cases due to the incorporation of PCMs. Consequently, $T_{\mathrm{o}}$ is also reduced. As this temperature can be used for the thermal comfort analysis, it is expected that the incorporation of PCMwallboards contributes to increase indoor thermal comfort.

Fig. 14 shows the cooling loads and temperatures profiles for the same scenarios presented in Fig. 13 considering that the cooling system is turned off from $2 \mathrm{pm}$ to $4 \mathrm{pm}$. For these EnergyPlus simulations, a maximum total cooling capacity of $3500 \mathrm{~W}$ was imposed in the ideal loads air system model. The results show that $T_{\mathrm{a}}$ rises above $30^{\circ} \mathrm{C}$ in all the rooms when the cooling system is turned off. For larger glazing areas, the indoor air temperature will be higher in the PCM-enhanced rooms. Moreover, when the system is turned on again at $4 \mathrm{pm}$, the cooling loads are higher for the rooms with PCM-wallboards. When the indoor temperature is lowered by the airconditioning, the PCMs will start discharging some sensible heat indoors and more energy will be required for cooling. Another important feature is that, during the cooling cut period, both $T_{\mathrm{mr}}$ and $T_{\mathrm{o}}$ will be higher in the models with PCM-wallboards. 


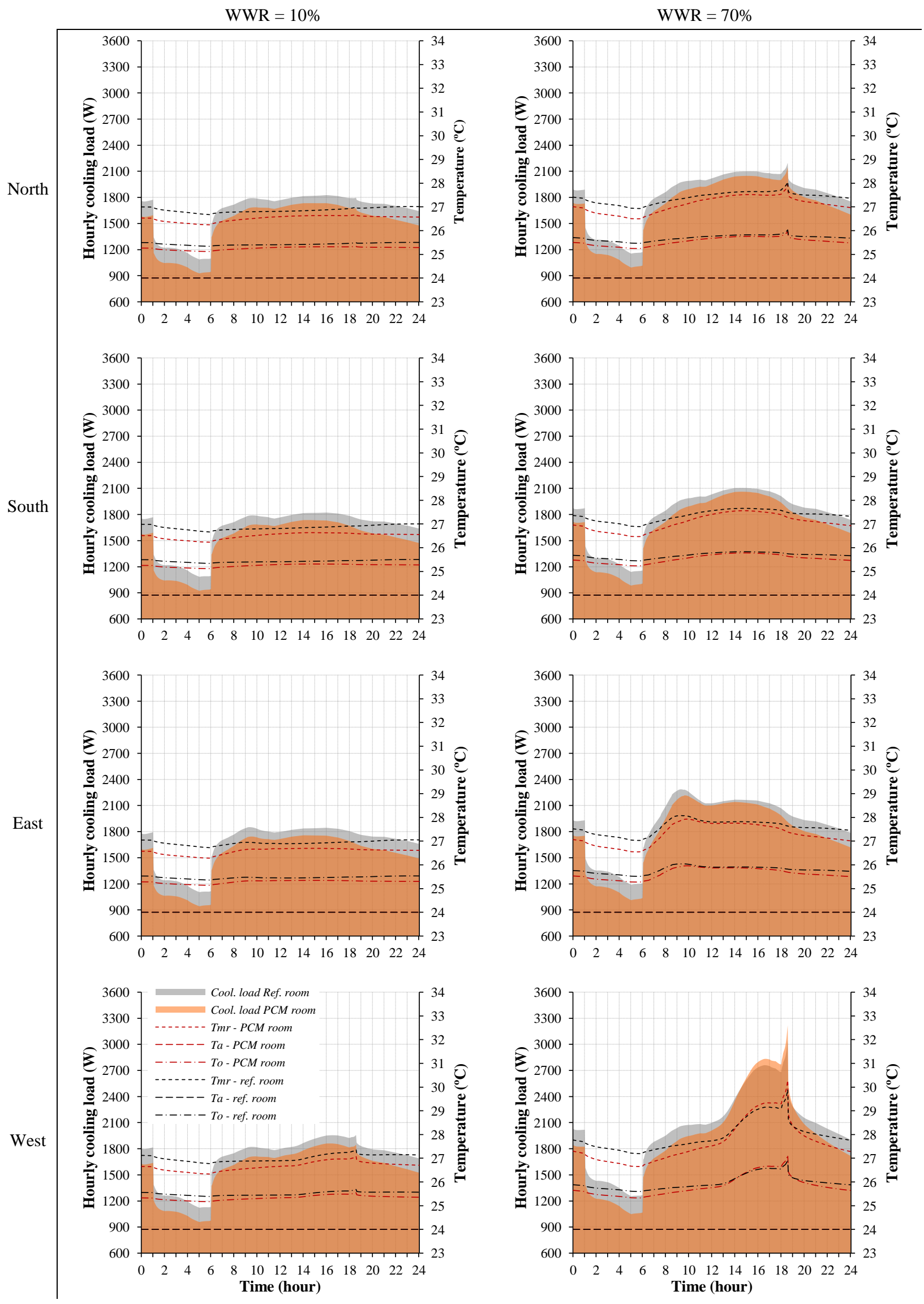

Fig. 13. Hourly cooling load profiles and evolution of the estimated temperatures for the cooling peak day $\left(5^{\text {th }}\right.$ of August) for both the reference and the PCM-enhanced models with WWR $=10 \%$ and $70 \% . T_{\text {th }}=24^{\circ} \mathrm{C}$. 


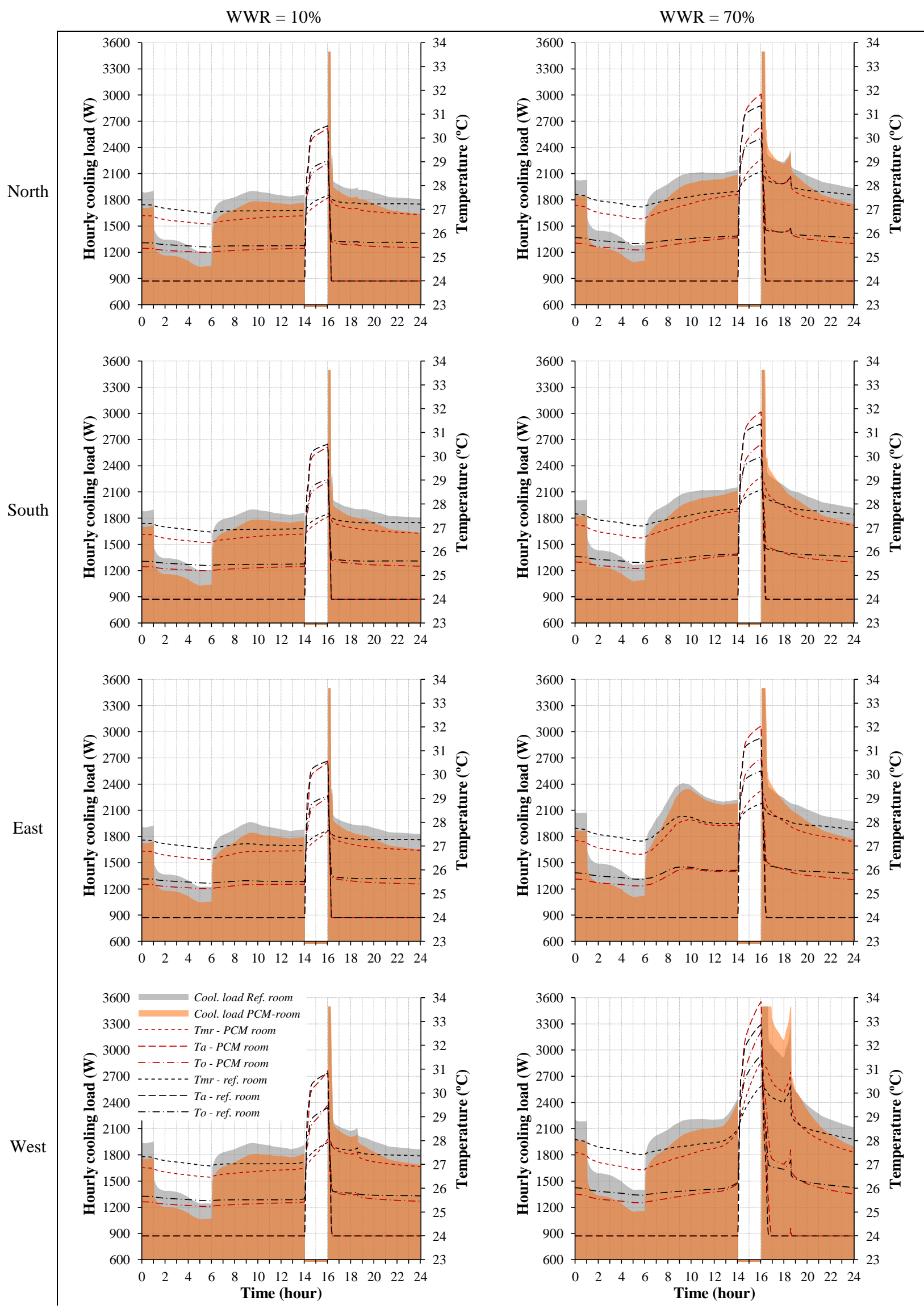

Fig. 14. Hourly cooling load profiles and evolution of the estimated temperatures for the cooling peak day $\left(5^{\text {th }}\right.$ of August) for both the reference and the PCM-enhanced models with WWR $=10 \%$ and $70 \%$. Cooling system turned off from $2 \mathrm{pm}$ to $4 \mathrm{pm}$ and $T_{\mathrm{th}}=24^{\circ} \mathrm{C}$. 
The results depicted in Figs. 14 and 14 also show that the incorporation of PCM-wallboards in Kuwait can be used to reduce the hourly cooling loads when the cooling system is operating continuously. On the other hands, if the cooling system stops working during the problematic summer peak hours, the inclusion of PCM-wallboards can have a negative impact, as it may increase the indoor air temperature. As explained before, the PCM volume is already melted at this point, and no extra latent heat storage capacity exists to contribute for reducing the rise of the indoor temperature.

\section{Conclusion}

This extensive EnergyPlus based parametric simulation study found that introducing PCM-wallboards in low-rise residential heavyweight construction in Kuwait generally helps to create nominal annual savings of useful energy for cooling and peak-loads reductions in the order of 5\%. Assuming that the majority of residential households in Kuwait will select setpoint temperatures between $22-26{ }^{\circ} \mathrm{C}$, a custom universal PCM-wallboard system with a thickness of $4 \mathrm{~cm}$ and a melting peak temperature of the $\mathrm{PCM}$ of $24^{\circ} \mathrm{C}$ is recommend for new construction in Kuwait. PCM-wallboards in Kuwait only reduce the hourly cooling loads if the cooling system operates continuously. However, if the cooling system stops working during the summer peak hours due to a blackout, the incorporation of PCM-wallboards may have a negative impact. Given current retail costs of electricity in Kuwait, PCM-wallboards are not economically attractive for use in air-conditioned heavyweight residential buildings.

The overall methodology proposed herein was focused on a single-zone room model. Hence, the results cannot be directly extrapolated and generalized to more complex models. Further work should be done to apply the presented methodology to more complex buildings and other sorts of construction (e.g. lightweight construction). Moreover, the output of this paper cannot be generalized to high-rise residential buildings nor to low/high-rise commercial buildings in Kuwait, because the internal loads, solar gains, occupation schedules, construction type, etc., would be significantly different from those considered to low-rise heavyweight residential buildings.

\section{Acknowledgments}

The first author acknowledges the support provided by the Portuguese Foundation for Science and Technology (FCT) through the PhD scholarship SFRH/BD/51640/2011 in the framework of the MIT-Portugal program, and the support provided by FEDER funds through the COMPETE 2020 (POCI), Portugal 2020 and FCT I.P. (PIDDAC) - project "PCMs4Buildings", ref. POCI-01-0145-FEDER-016750 (FEDER) | PTDC/EMSENE/6079/2014 (FCT). This work further contributed to Signature Project 1, "Sustainability of Kuwait's Built Environment," that was administered by the Kuwait-MIT Center for Natural Resources and the Environment. 


\section{Nomenclature}

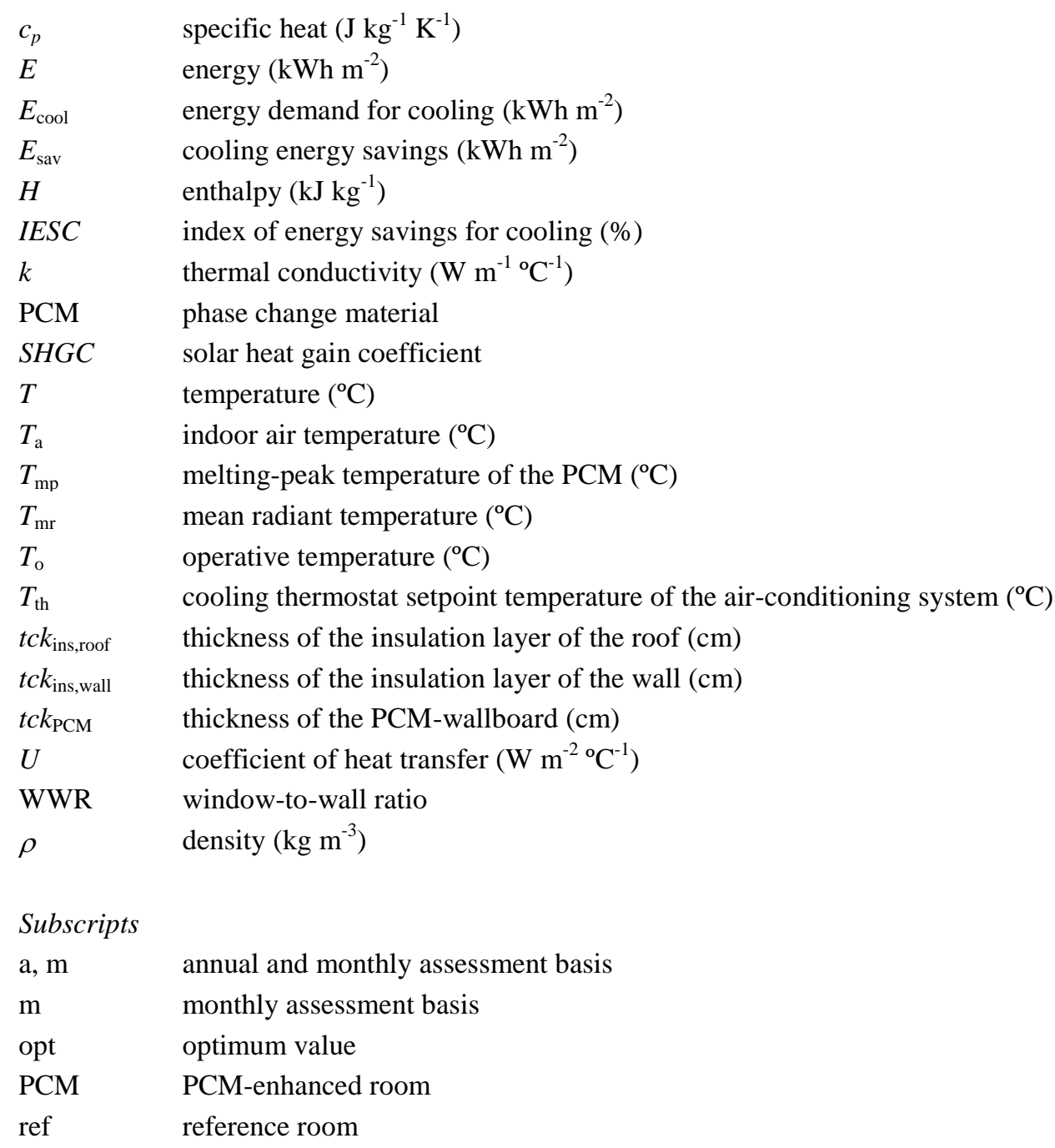

\section{References}

Al Tayyar I (2015). Success program save energy in mew, internal presentation Kuwait Ministry of Energy and Water.

Al-ajmi FF, Hanby VI (2008). Simulation of energy consumption for Kuwaiti domestic buildings. Energy and Buildings, 40:1101-1109.

Al-Mumin A, Khattab O, Sridhar G (2003). Occupants' behavior and activity patterns influencing the energy consumption in the Kuwaiti residences. Energy and Buildings, 35:549-559.

Alotaibi S (2011). Energy consumption in Kuwait: prospects and future approaches. Energy Policy, 39:637-643.

ANSI/ASHRAE (2004). Standard 140-2004, Standard method of test for the evaluation of building energy analysis computer programs, GA: American Society of Heating, Refrigerating, and Air-Conditioning Engineers, Atlanta, 2004.

Baetens R, Jelle BP, Gustavsen A (2010). Phase change materials for building applications: a state-of-the-art review. Energy and Buildings, 42(9):1361-1368. 
Cabeza LF, Castell A, Barreneche C, de Gracia A, Fernández AI (2011). Materials used as PCM in thermal energy storage in buildings: a review. Renewable and Sustainable Energy Reviews, 15(3):1675-1695.

Cao S, Gustavsen A, Uvsløkk S, Jelle BP, Gilbert J, Maunuksela J (2010). The Effect of Wall-Integrated Phase Change Material Panels on the Indoor Air and Wall Temperature - Hot box Experiments. Paper presented at the Renewable Energy Research Conference 2010, Trondheim, Norway.

David D, Kuznik F, Roux J-J (2011). Numerical study of the influence of the convective heat transfer on the dynamical behaviour of a phase change material wall. Applied Thermal Engineering, 31(16):3117-3124.

de Gracia A, Cabeza LF (2015). Phase change materials and thermal energy storage for buildings. Energy and Buildings, 103:414-419.

de Gracia A, Navarro L, Castell A, Cabeza LF (2015). Energy performance of a ventilated double skin facade with PCM under different climates. Energy and Buildings, 91:37-42.

EnergyPlus 8.0.0 (2014). Energy simulation software. Available at http://apps1.eere.energy.gov/buildings/energyplus/

Fraser M (2009). Increasing thermal mass in lightweight dwellings using phase change materials - a literature review. Built Environment Research Papers, 2(2):69-83. ISSN 1756-2473.

Gyptec Ibérica (2016). Tabela de preços placas de gesso e massas perfis e acessórios. Available at http://www.gyptec.eu/documentos/T_Precos_Gyptec.pdf. (in Portuguese).

Khudhair AM, Farid MM (2004). A review on energy conservation in building applications with thermal storage by latent heat using phase change materials. Energy Conversion and Management, 45(2):263-275.

Kuznik F, David D, Johannes K, Roux J-J (2011). A review on phase change materials integrated in building walls. Renewable and Sustainable Energy Reviews, 15(1):379-391.

Kuznik F, Virgone J (2009). Experimental investigation of wallboard containing phase change material: data for validation of numerical modeling. Energy and Buildings, 41(5):561-570.

Kuznik F, Virgone J, Johannes K (2011). In-situ study of thermal comfort enhancement in a renovated building equipped with phase change material wallboard. Renewable Energy, 36(5):1458-1462.

Kuznik F, Virgone J, Noel J (2008). Optimization of a phase change material wallboard for building use. Applied Thermal Engineering, 28(11-12):1291-1298.

Mandilaras I, Stamatiadou M, Katsourinis D, Zannis G, Founti M (2013). Experimental thermal characterization of a Mediterranean residential building with PCM gypsum board walls. Building and Environment, 61:93-103.

Ministry of Electricity and Water (2010). Energy Conservation Program - Code of Practice, MEW, R-6, $2^{\text {nd }}$ Ed. Kuwait.

Osterman E, Tyagi VV, Butala V, Rahim NA, Stritih U (2012). Review of PCM based cooling technologies for buildings. Energy and Buildings, 49:37-49.

Pomianowski M, Heiselberg P, Zhang Y (2013). Review of thermal energy storage technologies based on PCM application in buildings. Energy and Buildings, 67:56-69. 
Pullen T (2012). Homebuilding \& Renovation - Phase Change Materials. Available at https:/www.homebuilding.co.uk/2012/05/20/phase-change-materials/

Rae P (2014). Using Existing Governance to make retrofitting enhanced Energy Efficiency into Existing Buildings, Easy. Available at http://climatecolab.org/contests/2014/buildings/c/proposal/1309326

Reinhart CF, Cerezo C, Jones N, Hajiah A, Al-Mumin A (2015). Kuwait 2030: A Blueprint for Managing Kuwait's Building-related Energy Needs. Presentation to the Kuwait Foundation for the Advancement of Sciences (KFAS), Kuwait, Dec 3.

Saffari M, de Gracia A, Ushak S, Cabeza LF (2016). Economic impact of integrating PCM as passive system in buildings using Fanger comfort model. Energy and Buildings, 112:159-172.

Sharma A, Tyagi VV, Chen CR, Buddhi D (2009). Review on thermal energy storage with phase change materials and applications. Renewable and Sustainable Energy Reviews, 13(2):318-345.

Soares N, Costa JJ, Gaspar AR, Santos P (2013). Review of passive PCM latent heat thermal energy storage systems towards buildings' energy efficiency. Energy and Buildings, 59:82-103.

Soares N, Gaspar AR, Santos P, Costa JJ (2014). Multi-dimensional optimization of the incorporation of PCMwallboards in lightweight steel-framed residential buildings in different climates. Energy and Buildings, 70:411-421.

Tabares-Velasco P (2012). Energy impacts of nonlinear behavior of PCM when applied into building envelope. Paper presented at the ASME $20126^{\text {th }}$ International Conference on Energy Sustainability $\& 10^{\text {th }}$ Fuel Cell Science, Engineering and Technology Conference, San Diego, California.

Tabares-Velasco PC, Christensen C, Bianchi M (2012). Verification and validation of EnergyPlus phase change material model for opaque wall assemblies. Building and Environment, 54:186-196.

Tyagi VV, Buddhi D (2007). PCM thermal storage in buildings: a state of art. Renewable and Sustainable Energy Reviews, 11(6):1146-1166.

Zhang Y, Zhou G, Lin K, Zhang Q, Di H (2007). Application of latent heat thermal energy storage in buildings: state-of-the-art and outlook. Building and Environment, 42(6):2197-2209.

Zhou D, Zhao CY, Tian Y (2012). Review on thermal energy storage with phase change materials (PCMs) in building applications. Applied Energy, 92:593-605.

Zhu N, Ma Z, Wang S (2009). Dynamic characteristics and energy performance of buildings using phase change materials: a review. Energy Conversion and Management, 50(12):3169-3181. 